\begin{tabular}{c} 
Volume and Issues Obtainable at Center for Sustainability Research and Consultancy \\
Journal of Accounting and Finance in Emerging Economies \\
ISSN: 2519-0318 ISSN (E) 2518-8488 \\
Volume 6: Issue 3 September 2020 \\
CSRᄃ \\
Journal homepage: $\underline{\text { www.publishing.globalcsrc.org/jafee }}$ \\
\hline
\end{tabular}

\title{
An Instrument for Measuring National Readiness and Capacity to Participate in Global Knowledge Base Economy
}

\author{
${ }^{1}$ Tariq Mahmood Ali , ${ }^{2}$ Adiqa Kausar Kiani , ${ }^{3}$ Khaleel Malik
}

${ }^{1}$ Visiting Academic, Alliance Manchester Business School / Manchester Institute of Innovation Research, The University of Manchester, UK: tmapcst@gmail.com

${ }^{2}$ Associate Professor, FUUAST Scholl of Economics, Federal Urdu University of Science and Technology, Islamabad, Pakistan.

${ }^{3}$ Senior Lecturer, Alliance Manchester Business School / Manchester Institute of Innovation Research, The University of Manchester, UK.

\begin{tabular}{l} 
ARTICLE DETAILS \\
\hline History \\
Revised format: November 2019 \\
Available Online: December 2019 \\
Keywords \\
STI Composite Indicator, \\
Science Technology Innovation \\
(STI) Policy, Economic \\
Development, Science \\
Technology Innovation Index \\
(STII)
\end{tabular}

JEL Classification:

O14, O19, O11, O12

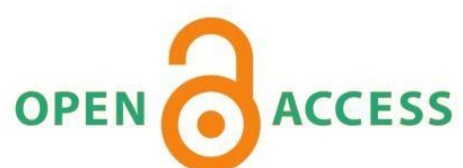

\begin{abstract}
An important question often asked is what are the determinants of science, technology and innovation (STI)? Is STI a measurable quantity? How can it be measured in quantitative terms? To answers these questions, a Science, Technology and Innovation Index (STII) has been developed for top 100 economies of the world on the basis of GDP, to evaluate, determine and measure the overall scientific, technological and innovative capacity and readiness of a country. The STII relies on four dimensions, each built around two or three pillars, each of which is composed of individual indicators, for a total of 44 STI indicators. The STI index is the average of aggregate of four dimensions. The economies are ranked on the basis of STII values and classified into six groups: i.e. leaders, potential leaders, dynamic adopters, slow adopters, marginalized and laggards. For more meaningful assessment of the STI capacities of nations, it captures the achievement gap of individual countries with the highest achiever. A comprehensive analysis into the strengths and weaknesses in different dimensions of STI capability of eight East South Asian countries is also provided. The results show that there are significant dispari $\neg$ ties between developed and developing nations in STI capacity and its various aspects. STI capacity and achievement gap analysis of individual countries provides useful information for STI policy makers to furnish their STI policies for increasing national capacity, and readiness to participate in the knowledge based economy.
\end{abstract}

(C) 2019 The authors, under a Creative Commons AttributionNonCommercial 4.0

Corresponding author's email address: tmapcst@ gmail.com

Recommended citation: Ali, T.M., Kiani, A. K. \& Malik K., (2019). An Instrument for Measuring National Readiness and Capacity to Participate in Global Knowledge Base Economy. Journal of Accounting and Finance in Emerging Economies , 6(3), 669-692 


\section{Introduction}

Change in the state of science, technology and innovation (STI) is one of the major driving forces of the long run economic growth and development, and social changes in living standard of people of a country. Also technological changes and innovations bring about scientific development. The transformation of a country from developing to developed country cannot be simply achieved by possession of natural resources, knowledge and information. Transformation also requires diffusion \& adoption of scientific principals or implementation of innovative technologies. STI activities not only accelerate the economic growth and bring about the social changes of lives but also enhance the capability to create, transmit and use STI knowledge (Ertl et al, 2006). Consequently, the transformation to a knowledge based economy is required in order to attain STI based global competitiveness. Knowledge and technology have become increasingly complex, escalating the significance of relationships among different countries to acquire specialized knowledge. Countries formulate economic policies that enhance the STI environment in the society and economy, which is very important for sustainable economic growth and development and global competitiveness (Sener and Saridogan, 2011). But the question arises how would the outcomes and impact of knowledge and STI activities be measured? Although there is abundant information available about STI activities, this mainly relates to input. For example, how many people are involved in this activity?, how much expenditure is committed to research and development (R\&D)? and what is nature of STI activity? However, these pieces of information do not help to fully understand measuring outcomes and impact of STI activities.

Although, some current science and technology indicators are composed of by World Bank, UNESCO, WIPO, UNDP, OECD and many other organizations. These S\&T indicators give insight about the output and input of STI activities. But still, there is need to organize, explore and investigate more sophisticated measures of potential value addition in the economy and their longer-term implications on economic growth and development. There is dire need to develop the most appropriate and suitable measure base on STI composite indicators to assess the STI activities. STI composite indicators serve many purposes including: used to evaluate policy measures; providing information on the current state of STI activities in a country; providing input for benchmarking STI performance with other countries; and helping to understand how various parts of economy and society are interconnected. Hence the outcome and impact of indicators are crucial for evidence based policy, resource allocation and accountability requirements (Gault, 2006).

S \& T statistics provide a distinct individual picture of different aspects of STI in relation to the economy but fail to provide a broader picture of strengths, weaknesses, and opportunities, on the national level. For example, statistics of national research and development (R\&D) expenditure, number of R\&D institutes and university enrollment in science and engineering give clear picture in these areas of national STI system but individual indicators are unable to explain the strength, efficiency and their impact on the economic growth \& development and national STI system comprehensively. The study attempts to shed light on how STI composite indicators can be measured in terms of index, namely, Science, Technology and Innovation Index (STII). The STII is the average of an aggregate of four dimensions, each built around two or three pillars, each of which is composed of individual indicators, for a total of 44 indicators which explain the overall scientific, technological and innovative development of a country in quantitative terms

In many indices, technological capacities of a country are measured through combining input and output STI indicators. The combining of the input and output indicators in the form of index provide limited logical information. For example, the Georgia Tech High Technology Index is developed with a more systematic framework, is better in terms of public use. While some indices (like Porter and Stern, 2003) were developed only for OECD countries, they cannot be applied to developing countries. The developing economies have different situations and scenarios compared to developed ones. For example, the patent is considered one of the most important STI composite indicator for innovation used in the construction of 
many indices, while in developing economies patents are not the major source for innovation, since productivity gain is seen to be more important in (Chinaprayoon, 2007).

The major shortcoming in indices (like Global Competitive Index and Global Innovation Index) is that these indices are compiled upon perception and surveys data rather than original STI composite indicators. Therefore, there is a need to develop a comprehensive index based on real STI composite indicators and represents both developed and developing economies like HDI. The current study attempts to develop the STII based on 44 STI composite indicators that provides the exact STI situation of the country.

Following are the research questions:

- What are the determinants of science, technology and innovation (STI) progress?

- Is STI a measurable quantity? If yes, then how can it be measured?

On the basis of research questions, we have the following objectives:

- To find out the determinants of STI progress.

- To develop STII based on 44 composite STI indicators.

The contribution of the study aims to provide researchers and economists new insights on how STI progress can be measured and assessed quantitatively and numerically. The study contributes to our understanding of why a scientifically and technologically lagging country might be economically underdeveloped. It also aims to provide a more robust analysis about the notion of a knowledge based economy, including insights about weaknesses, strengths, and opportunities of an STI system of a country nationally and in an international context. We aim to provide thought provoking implications for policy makers and planners for the formulation and implementation of STI capacity of a country.

Although many developing countries might have access to good natural resources, they are often unsuccessful in materializing these resources into visible phenomenon due to lack of technological capabilities. The study also explores why developing countries need to make significant investments in R\&D to enhance their scientific and technological capabilities.

One other, significance of the study is that STI composite indicators are used to rank different countries taking into consideration different aspects of STI. Composite S\&T indicators (especially STI Index) would be very useful for policy makers to formulate STI policy measures and approaches to augment countrywide competencies in order to compete with other nations in a global framework.

\section{Literature Review}

Cross-country differences exist in competing STI based global marketplace and in the utilization of STI as a tool for human development. This indicates the variation among countries in STI capacity. Scientific and technical progress plays a vital role in the development of any country. Therefore, STII progress always remains a matter of interest for S\&T planners, policy makers and economists. For the formulation of STI policies, policy makers of developing countries depend on the basic STI statistics (Ali et al., 2014). Different studies have been carried out to address the question of whether STI is a measurable quantity in terms of STI composite indicators? Some well-known STI composite indicators are: WEF Technology Index introduced first time as a part of the Growth Competitiveness Index (GCI) in the Global Competitiveness Report (GCR) 2001-2002 which was published by World Economic Forum (WEF) in 2002 (WEF, 2002). The Technology Index composes of three sub-indices: i) Innovation sub-index measured by innovation survey questions and innovation hard data (US utility patents granted per million 
population and gross tertiary enrolment rate), ii) Technology transfer sub index measured by technologyin-trade residual and survey data and iii) Information and communication technology (ICT) sub-index measured by number of mobile telephones, internet users, internet hosts, telephone mainlines, personal computers per capita and survey data. Technology index was based on two indices: index of technological core economies and technological non-core economies. Technology Index for core economies was calculated by the addition of $1 / 2$ of innovation and $1 / 2$ ICT sub-indexes while noncore technology index was calculated by addition of $1 / 8$ innovation sub-index, $3 / 8$ technology transfer sub-index, and $1 / 2$ ICT sub-index

National Innovative Capacity Index (NICI) was introduced by Michael Porter and Scott Stern in the Global Competitiveness Report (GCR) 2001-2002 published by World Economic Forum (WEF) in 2003 (WEF, 2003). They used 2003 Executive Opinion Survey to assess the innovative capacity of 78 countries for which the required data were available. They argued that innovative capacity is to create the stream of commercially relevant innovations for both political and economic activity. They argued that NICI is composed of five indices: i) the innovation policy sub-index, ii) the cluster innovation environment subindex, iii) the scientific and engineering manpower sub-index, iv) the linkages sub-index and v) the company operation sub-index (Porter and Stern, 2003).

Science and Technology Capacity Index-2002 (STCI-02) was developed by Wagner et al (2000). This index updated and improved an earlier index that was published by the RAND Corporation (Wagner et al, 2000). The index states "the ability of a country to absorb and retain specialized knowledge and to exploit it to conduct research, meet needs and develop efficient products and processes". The index composes of three dimensions. Each dimension is measured by two or more than two indicators: i) enabling factors (measured by GDP per capita and tertiary enrollment in science), ii) resources (measured by the number of scientists and engineers, number of institutions and R\&D expenditures) and iii) embedded knowledge (measured by patents, S\&T journal articles and co-authorship publications). Wagner et al. (2000) awarded different weightage to different dimensions. Utilizing this methodology, they evaluated 150 countries for science and technology capacity and categorized them into following four groups according to their overall scientific capacity:

'Scientifically advanced countries'-22 countries with scientific capacity well above the international mean;

- 'Scientifically proficient countries'- 24 countries which also have positive standing in scientific capacity when compared to the rest of the world;

- 'Scientifically developing countries' - 24 countries with some features of scientific capacity, and where the trend in spending is positive but whose scientific capacity is below the international mean;

- 'Scientifically lagging countries'- 80 countries with little data indicating scientific capacity.

Desai et al. (2002) proposed a Technology Achievement Index (TAI) and introduced earlier by UNDP in its 2001 Human Development Report (UNDP, 2001). TAI is measurement approach to assess the technological achievements of a country by concentrating on its capacity in creating and using technology. They assessed technology achievements of a country through four dimensions: 'creation of new technology'; 'diffusion of recent innovations'; 'diffusion of old innovations'; 'human skills'. Desai et al. (2002) evaluated 72 countries on the basis of technology achievement index. They placed countries into four groups as follows:

- Leaders: Those at the cutting edge of innovation. These are highly developed countries.

- Potential leaders: Those with high skill levels, who have diffused old technologies (electricity and water supply networks), but innovate little. 
- Dynamic adapters: Those rapidly expanding their use of new technologies (e.g., the internet, mobile phones), who have important high technology industries, but where the diffusion of old technologies has been slow and incomplete.

- Marginalized countries: Where skill levels are very low, with large proportions of the population yet to receive benefits from the diffusion of old technology.

Industrial Development Scoreboard (IDS) was published by UNIDO in its Industrial Development Report (IDR) (UNIDO, IDR, 2003; UNIDO, IDR, 2004, Lall and Albaladejo, 2003) influence UNIDO's effort is strongly inspired by the work of (Archibugi and Coco, 2004). They argued that industrial performance can be measured by the following four categories:

- Technological activity is measured by $R \& D$ financed by productive enterprise and number of patents registered at USPTO.

- Competitive industrial performance is measured by manufactured value added (MVA) per capita, manufactured export per capita, and the share of medium and high technology (MHT) in manufactured exports.

- Technology imports are measured by FDI, foreign license payments and capital goods imports.

- Skills and ICT infrastructure is measured by technical enrollment at the tertiary enrollment in science, engineering and mathematics and computing and telephone mainlines.

Competitive Industrial Performance (CIP) index was introduced by UNDP and published in IDR 2002/2003 and IDR 2004. The results of CIP index of 87 countries were presented by the UNDP in IDR 2002/2003. UNDP extend the CIP index up to 93 countries in IDR 2004 (UNIDO, 2004). Although the IDR-2005 did not publish a CIP index, they mention six indicators of industrial performance including MVA per capita, manufactured export per capita, the share of manufactured export in total output (GDP), the share of MHT production in MVA, and share of MHT in manufactured export. This report also presented the new index of industrial technological achievement known as industrial-cum technological advance (ITA) index, which indicates another good attempt to construct STI indicator for developing countries (UNIDO, 2005).

Industrial-cum-technological advance (ITA) was reported in its Industrial Development Report 2005 (UNIDO, 2005) by UNIDO (UNIDO, 2005). ITA index is used to represent the salient features of economy emphasizing the role of industry and technology and their relation and to give other indicators for representing economy. ITA composes of two dimensions: industrial advance dimension stands on the share of manufacturing in GDP and the share of manufactures in total export; technological advance dimension stands on the share of medium-or-high technology activities in manufacturing value added (MVA) and the share of medium-or-high technology activities in total export. The results of ITA index are very interesting for some of the developing countries which are ranked in the category of "high performer" ahead of many industrialized countries (UNIDO, 2005).

European Commission launched the European Innovation Scoreboard (EIS) and its Summary Innovation Index (SII) (European Commission, 2004). EIS is considered a good yardstick to measure and compare the innovative performance of European Union (EU) member states. Innovation indicators like Community Innovation Survey (CIS) indicators and non-CIS indicators, and trend analysis for 25 EU member countries and 8 non-EU countries are jointly used to construct the EIS, while SII is measured by gathering 19 non-CIS innovation indices.

High Technology Indicators (HTI) was constructed by Porter et al (2006) comprising of four composite input indicators and output indicators. HTI developed the new four composite indicators i.e National Orientation (NO), Socioeconomic Infrastructure (SI), Technological Infrastructure (TI) and Productive 
Capacity (PC) which jointly constructs the input indicators while the Technological Standing (TS) takes as output indicator which indicates the overall success in exporting high technology products. They collected the data from 33 countries through international survey and hard statistics (Porter et al, 2006).

Archibugi and Coco (2004) developed the New Indicator of Technological Capabilities (referred to as ArCO) which stands on three dimensions: i) creation of technology (based on patents registered at USPTO and scientific articles); ii) technological infrastructures (based on internet penetration, telephone penetration, and electricity consumption); iii) the development of human skills (based on tertiary science and engineering enrolment, mean years of schooling, and literacy rate). The main objective of that study was to develop a tool for measuring technological capabilities of both developed and developing countries. Countries coverage in ArCO is 162. Furthermore, Archibugi and Coco (2004) attempted to explain this indicator by including another influential component i.e. technology import (based on FDI, technology licensing payments and capital goods imports. With inclusion of this variable, the number of countries studied fell to 86 countries.

In 2007, Cornell University, INSEAD and World Intellectual Property Organization begun to publish the Global Innovation Index (GII) which is published each year. The GII is an evolving project that builds on its previous editions while incorporating newly available data. The GII stands on two sub-indices: (1) the Innovation Input sub-index measured by five sub-pillars- i) institutions, ii) human capital and research, iii) infrastructure, iv) market sophistication, and v) business sophistication; and the Innovation Output index measured by two sub-pillars- i) knowledge and technology outputs and ii) creative outputs. Each sub-pillar is constituted of individual indicators (81 in total in 2017). GII focuses provides an instrument that can furnish policies to enhance the long-term output growth, increase productivity and job growth (University, INSEAD, \& WIPO, 2017).

Tabatabaeean et al. (2010) developed Technological Capability Monitoring Index, based on seventeen indicators but did not have any sub-indices or dimensions. In the Index, 127 countries are ranked in three groups: large economy, medium economy and small economy based on the size of their GDP. Nasir et al. (2011) developed a technology achievement index referred as TAI-09, by applying the methodology of Desai et al. (2002) in which they studied the existing technological capabilities and capacities of 91 countries.

Since 2005, WEF has been publishing the Global Competitiveness Index (GCI) based on the original idea of Klaus Schwab (1979), developed by Xavier Sala-i-Martín in collaboration with the World Economic Forum. The GCI gathers 114 indicators that used to measure the matter for productivity and long-term prosperity. The GCI is constructed on 12 pillars and their respective indicators. The 12 pillars are i) institutions, ii) infrastructure, iii) macroeconomic environment, iv) health and primary education, v) higher education and training, vi) goods market efficiency, vii) labour market efficiency, viii) financial market development, ix) technological readiness, $\mathrm{x}$ ) market size, xi) business sophistication, and xii) innovation (Schwab and Sala-i-Martín, 2017).

Most of the studies carried out so far are about the technical performance of developed countries, while very few studies discuss performance of developing countries. Studies with a limited geographical, organizational and regional focus are almost non-existent; one exception being the Technology Achievement Index for Organization of Islamic Cooperation (OIC) member countries (referred as TAI13-OIC) (Ali et al., 2014). Ali et al. (2015) conducted another study, in which the Technology Achievement Index (TAI) for 41 of the OIC member states was presented (TAI-14-OIC). They concluded that though most of the OIC countries are rich in natural resources, they are unable to utilize them completely for their socio-economic development due to lack of scientific and technological capability.

Bashir (2015) developed the Global Science, Technology and Innovation Capacity (GSTIC) index based on nine pillars which reflects the national STI capacities of the countries: technology creation, $R \& D$ 
capacity, R\&D performance, technology absorption, diffusion of old technologies, diffusion of recent innovations, exposure to foreign technology, human capital and enabling factors. He ranked 167 countries with the GSTIC and categorized them into four groups: leaders, dynamic adopters, slow adopters and laggards. The results show that there are large differences between nations in STI capacity, with developing countries far behind in some areas relative to developed nations. Recently, Ali (2017) developed the TAI of 100 top economies to examine the position of countries, technological progress for the 21 years spanning 1995 to 2015. Countries have been ranked on their TAI which is based on four pillars; technology creation, diffusion of older innovations, diffusion of recent innovations and development of human skills.

\subsection{Critical Review of Literature of Composite STI Indices Studies}

The composite STI indicators and different indices have been discussed in the above section. Most of them are about the developed economies, only four like Science Technology Capacity index, Technology Achievement index, Global Science, Technology and Innovation Capacity index are also used for developing economies.

Many STI composite indicators were constructed before the 2000s when data of S\&T indicators were not easily available. For developing composite indicators, two things are very important; one is what types of indicators would be included and other is how to weight each indicator or dimension or pillar. Most of the indices used a very simple methodology to weight the indicators or components while very latest statistics are available. Probably, it may be used to develop the indices rather than more rigorous weighting procedure to construct an STI composite indicator.

In many indices, technological capacities of a country are measured through combining input and output STI indicators. The combining of the input and output indicators in the form of index provide limited logical information. For example, the Georgia Tech High Technology Index is developed with a more systematic framework, is better in terms of public use. While some indices (like Porter and Stern, 2003) were developed only for OECD countries, they cannot be applied to developing countries.

Developing economies have different scenarios compared to developed economies. For example, the patent is considered one of the most important STI composite indicators for innovations used in the construction of many indices, while in developing economies patents are not the major source for innovation, instead productivity gain is seen to be more important in developing economies than slight or incremental technological change (Chinaprayoon, 2007). Intarakumnerd and Viotti (2006) proposed that "the diffusion of imported technologies" might not be important to developed economies compared to the developing economies.

The major shortcoming in indices (mentioned above like GCI and GII) is that they used survey data to construct the index. These indices are based on perception and surveys, rather than original STI composite indicators. Therefore, there is dire need to develop a comprehensive index which is based on real STI composite indicators and represent both developed and developing economies like HDI. The current study attempts to develop the Science, Technology and Innovation Index (STII), which is based on 44 STI composite indicators that provides the exact STI situation of the country.

\section{Science, Technology and Innovation Index (Stii)}

\subsection{Conceptual Framework of Science, Technology and Innovation Index (STII)}

When a country reviews its STI policies, a useful starting point is the realistic assessment of its current STI progress. The STII helps to create an environment in which STI factors are under continual evaluation and provides a key tool \& rich database of detail metrics for refining STI policies. The STII, a composite index of achievement in STI reflects the level of scientific, technological and innovative 
progress and thus the capacity of a country to participate in the network age. The STII is not meant to be the ultimate and definitive ranking of economies with respect to STI activities. Measuring STI activities (outputs) and its impact is difficult; hence great stress is placed on measuring the climate and infrastructure for STI and assessing related outcomes. The STII helps a country situate itself relative to others, especially those that are ahead. Although the end results take the shape of several rankings, the STII is more concerned with improving the 'journey' in order to better measure and understand STI and with identifying targeted policies, good practices, and other factors that foster STI activities (University, INSEAD \&WIPO, 2015). The STII is proposed to be used as a starting point to make an overall assessment, to be followed by examining different indicators in greater detail. STII shows how much STI output a given country is getting from its inputs. The STII relies on four dimensions, each built around two or three pillars, each of which is composed of individual indicators, for a total of 44 indicators (Figure 1 and Table 1).

Table 1. Conceptual Frame Work of STII and Data Sources

\begin{tabular}{|c|c|c|c|c|}
\hline $\begin{array}{l}\text { Dimension } \\
\text { S }\end{array}$ & Pillars & & Indicators & Sources \\
\hline \multirow{10}{*}{$\begin{array}{l}\text { Support } \\
\text { for STI } \\
\text { activities }\end{array}$} & \multirow{4}{*}{$\begin{array}{l}\text { Enabling } \\
\text { factors } \\
\# 1\end{array}$} & 1. & Per capita GDP (constant 2005 US\$) & \multirow{4}{*}{$\begin{array}{l}\text { World Bank, } \\
\text { WDI 2017, } \\
\text { UNESCO } \\
\text { Institute } \\
\text { Statistics } \\
\text { (UIS) }\end{array}$} \\
\hline & & 2. & Adult literacy rate & \\
\hline & & 3. & Tertiary Science Enrollment & \\
\hline & & 4. & Expenditure on education as \% of GDP & \\
\hline & \multirow{3}{*}{$\begin{array}{l}\text { Resources } \\
\# 2\end{array}$} & 5. & Total R\&D personnel (FTE) & \multirow{3}{*}{$\begin{array}{l}\text { UNESCO } \\
\text { Institute of } \\
\text { Statistics(UIS } \\
\text { ) }\end{array}$} \\
\hline & & 6. & Number of universities in top ranks $(10,004)$ & \\
\hline & & 7. & $\begin{array}{l}\text { Gross Domestic Expenditure on Research and } \\
\text { Development (GERD in '000 PPP\$ (in constant } \\
\text { prices - 2005) }\end{array}$ & \\
\hline & \multirow{3}{*}{$\begin{array}{l}\text { Human skills } \\
\text { development } \\
\# 3\end{array}$} & 8. & $\begin{array}{l}\text { Gross enrolment ratio primary to tertiary, both } \\
\text { sexes }(\%)\end{array}$ & \multirow{3}{*}{$\begin{array}{l}\text { UNESCO } \\
\text { Institute of } \\
\text { Statistics; } \\
\text { Index Mundi } \\
\text { website (for } \\
\text { missing data) }\end{array}$} \\
\hline & & 9. & $\begin{array}{l}\text { Percentage of students in tertiary education } \\
\text { enrolled in Engineering, Manufacturing and } \\
\text { Construction programmes, both sexes }(\%)\end{array}$ & \\
\hline & & 10 & $\begin{array}{l}\text { Pupil-teacher ratio in tertiary education } \\
\text { (headcount basis) }\end{array}$ & \\
\hline \multirow{7}{*}{ R\&D } & \multirow{4}{*}{$\begin{array}{l}\text { R\&D } \\
\text { capacity } \\
\# 4\end{array}$} & 11 & $\begin{array}{l}\text { Researchers (full-time equivalent) per million } \\
\text { inhabitants }\end{array}$ & \multirow{4}{*}{$\begin{array}{l}\text { UNESCO } \\
\text { Institute of } \\
\text { Statistics }\end{array}$} \\
\hline & & 12 & $\begin{array}{l}\text { Technicians (full time equivalent) per million } \\
\text { inhabitants }\end{array}$ & \\
\hline & & 13 & $\begin{array}{l}\text { Gross Expenditure on } \\
\text { expenditure as \% of GDP }\end{array}$ & \\
\hline & & 14 & GERD (PPP\$) per researcher & \\
\hline & \multirow{3}{*}{$\begin{array}{l}\text { R\&D } \\
\text { performance } \\
\text { \# } 5\end{array}$} & 15 & $\begin{array}{l}\text { Number of scientific articles per million } \\
\text { population }\end{array}$ & \multirow{3}{*}{$\begin{array}{l}\text { Scimago } \\
\text { Journal \& } \\
\text { Country Rank } \\
\text { website, UIS }\end{array}$} \\
\hline & & 16 & Number of citations per publication & \\
\hline & & 17 & H-Index of publications & \\
\hline \multirow{2}{*}{ Knowledge } & \multirow{2}{*}{$\begin{array}{l}\text { Embedded } \\
\text { knowledge } \\
\text { \# } 6\end{array}$} & 18 & $\begin{array}{l}\text { Total patent grants (direct and PCT national } \\
\text { phase entries) to resident }\end{array}$ & \multirow{2}{*}{$\begin{array}{l}\text { WIPO, UIS, } \\
\text { and Scimago } \\
\text { Journal } \& \\
\text { Country Rank }\end{array}$} \\
\hline & & 19 & 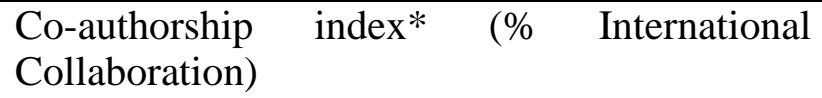 & \\
\hline
\end{tabular}




\begin{tabular}{|c|c|c|c|c|}
\hline & & 20. & Scientific and technical (S\&T) journal articles & website \\
\hline & & 21. & Total No. of Publications & \\
\hline & & 22. & $\begin{array}{l}\text { High-technology exports as \% of manufactured } \\
\text { exports }\end{array}$ & $\begin{array}{l}\text { World Bank, } \\
\text { World }\end{array}$ \\
\hline & Absorption & 23. & $\begin{array}{l}\text { Charges for the use of intellectual property, } \\
\text { receipts (BoP, current US\$) }\end{array}$ & $\begin{array}{l}\text { Development } \\
\text { Indicators }\end{array}$ \\
\hline & O1 & 24. & Outward FDI stock per capita & 2017 \\
\hline & & 25. & Computer and communications service exports & UNESCO \\
\hline & & 26. & ICT goods exports (\% of total goods exports) & $\begin{array}{l}\text { Institute of } \\
\text { Statistics(UIS } \\
\text { ) }\end{array}$ \\
\hline & & 27. & $\begin{array}{l}\text { Total patent applications (direct and PCT } \\
\text { national phase entries) per million population. }\end{array}$ & \\
\hline & & 28. & $\begin{array}{l}\text { Total patent Application (direct and PCT } \\
\text { national phase entries) of residents per million } \\
\text { population }\end{array}$ & World \\
\hline & $\begin{array}{l}\text { Creation of } \\
\text { knowledge }\end{array}$ & 29. & $\begin{array}{l}\text { Total design applications (direct and via the } \\
\text { Hague system) per million inhabitants }\end{array}$ & $\begin{array}{l}\text { Intellectual } \\
\text { Property }\end{array}$ \\
\hline & & 30. & $\begin{array}{l}\text { Total design registrations (direct and via the } \\
\text { Hague system) }\end{array}$ & $\begin{array}{l}\text { Organization } \\
\text { (WIPO). }\end{array}$ \\
\hline & & 31. & $\begin{array}{l}\text { Total utility model applications (direct and } \\
\text { PCT national phase entries) }\end{array}$ & \\
\hline & & 32. & $\begin{array}{l}\text { Total utility model grants (direct and PCT } \\
\text { national phase entries) }\end{array}$ & \\
\hline & Diffucion of & 33. & Electric power consumption (kWh / capita) & World Bank, \\
\hline & old & 34. & $\begin{array}{l}\text { Fixed telephone }+\underset{\text { Mobile }}{\text { cellular }} \\
\text { subscriptions (per } 100 \text { people) }\end{array}$ & $\begin{array}{l}\text { World } \\
\text { Development }\end{array}$ \\
\hline & & 35. & Gross fixed capital formation (\% of GDP) & $\begin{array}{l}\text { Indicators } \\
2017\end{array}$ \\
\hline & & 36. & Internet users (/1000 people) & \\
\hline & & 37. & Imports of goods and services (\% of GDP)) & \\
\hline $\mathrm{sem}^{\circ}$ & & 38. & $\begin{array}{l}\text { Number of households with a computer per } \\
100 \text { inhabitants }\end{array}$ & $\begin{array}{l}\text { The } \\
\text { International }\end{array}$ \\
\hline Innovation & Diffusion of & 39. & $\begin{array}{l}\text { Fixed broadband internet subscribers per } 100 \\
\text { inhabitants }\end{array}$ & $\begin{array}{l}\text { Telecommuni } \\
\text { cation Union }\end{array}$ \\
\hline & recent & 40. & Energy imports, net (\% of energy use) & World Bank, \\
\hline & \# 10 & 41. & $\begin{array}{l}\text { Charges for the use of intellectual property, } \\
\text { payments (BoP, current US\$) }\end{array}$ & $\begin{array}{l}\text { World } \\
\text { Development }\end{array}$ \\
\hline & & 42. & FDI Inward stock & Indicators \\
\hline & & 43. & $\begin{array}{l}\text { Communications, computer, etc. (\% of service } \\
\text { imports, BoP) }\end{array}$ & 2017 \\
\hline & & 44. & ICT goods imports (\% total goods imports) & \\
\hline
\end{tabular}




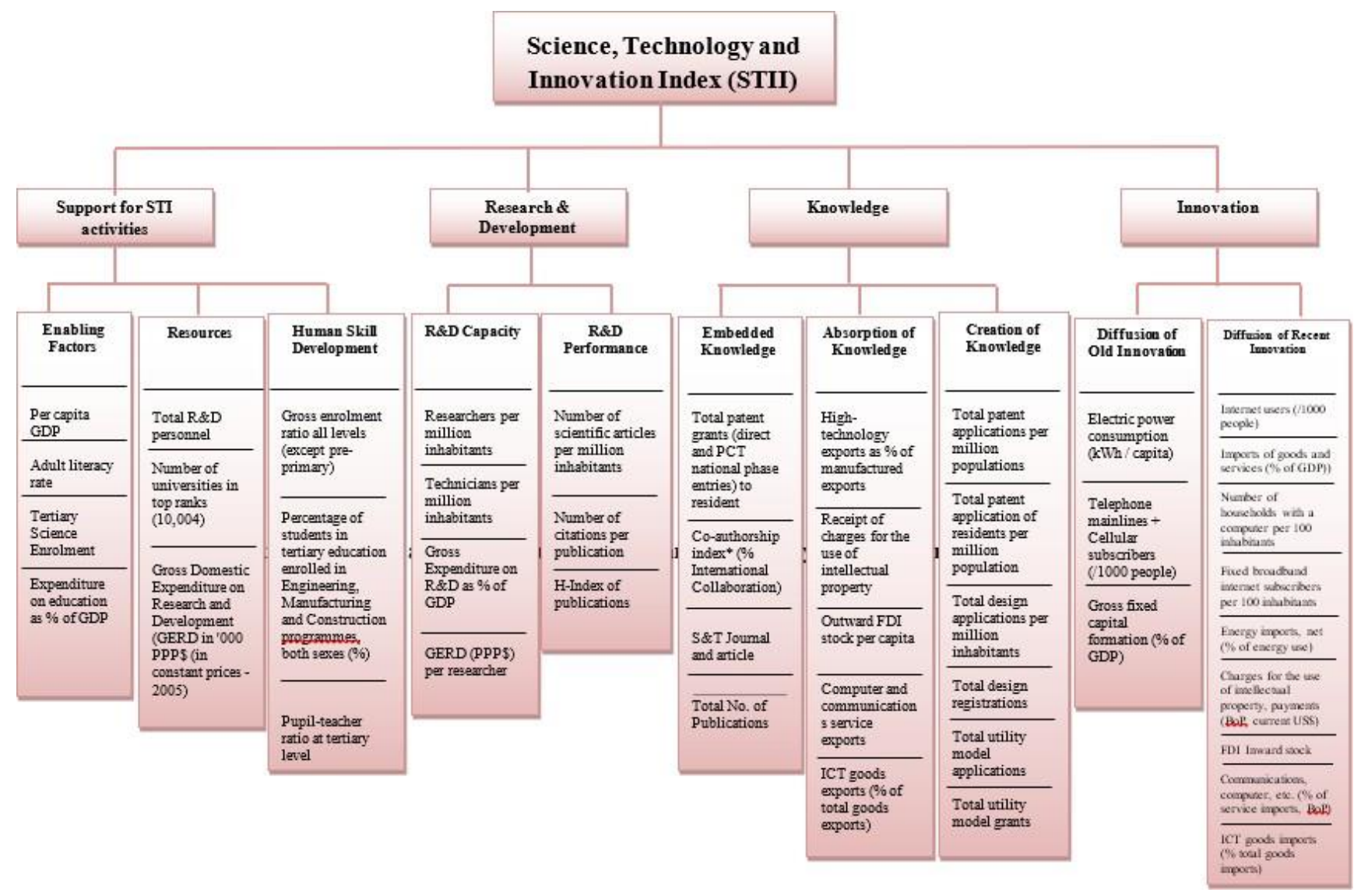

\subsubsection{Support for STI Activities}

The school, college and universities are considered the source of STI activities and knowledge generation. The government investment in basic science research, engineering and technology should pay off in the long run. Thus it could be argued that some features are necessary to support STI, while other features are sufficient to support it. The necessary features are i) scientists and engineers, ii) institutions for research and iii) funds for research and development. These three variables relate directly to S\&T capacity. The other variables either measure the boundary conditions or the environment for S\&T or reflect the results of its application to scientific and technological production. The support for STI activities is captured by three pillars:

\section{Pillar I: Enabling factors}

Enabling factors that help to create an environment conducive to the absorption, retention, production and diffusion of knowledge (Wagner et al., 2002). The enabling factor is measured by four indicators: Per capita GDP (constant 2005 US\$); Adult literacy rate; Tertiary Science Enrolment; Expenditures on education as \% of GDP.

\section{Pillar II: Resources}

Resources that can be devoted to $S \& T$ activities, which are concerned with the indicators that are mostly related to S \& T capacity (Wagner et al., 2002). Resources are composed of three indicators: Total R\&D personnel (Full Time Equivalent (FTE)); Number of universities in top ranks (10,004); Gross Domestic Expenditure on Research and Development (GERD in '000 PPP\$ (in constant prices - 2005).

\section{Pillar III: Human skills}

A critical mass of skills is indispensable to technological dynamism. Both creators and users of new 
technology need skills. Today's technology requires adaptability — skills to master the constant flow of new innovation. The foundations of such ability are the basic education to develop cognitive skills and skills in science and mathematics. Three indicators are used for measuring human skill: Gross enrolment ratio of primary to tertiary, both sexes $(\%)$; Percentage of students in tertiary education enrolled in Engineering, Manufacturing and Construction programmes, both sexes (\%); Pupil-teacher ratio in tertiary education (headcount basis).

\subsubsection{Research and Development $(\mathrm{R} \& D)$}

Some STI activities specifically focus on carrying out R\&D with the purpose of creating new product or processes, and improving existing products or processes. It is unanimously agreed by all schools of thought (in economics) that R\&D affects the economic growth and development in the long run. Here $\mathrm{R} \& \mathrm{D}$ is captured by two pillars.

\section{Pillar IV: R\&D Capacity}

$\mathrm{R} \& \mathrm{D}$ is a crucial component of the innovation process and a key factor in capturing competitive advantages. Some economies or companies rely on R\&D for growth through new product introduction while many others use $R \& D$ to stimulate incremental improvements. R\&D capabilities of a country indicate how it will be successful in future in developing new products, processes and services. It also indicates the extent of benefits that can be derived from foreign technologies through adaptation. It also shows the ability of a country in using present and related knowledge for solving local problems (Bashir, 2015). R\&D capacity is gauged by the following four indicators: Researchers (full-time equivalent) per million inhabitants; Technicians (full-time equivalent) per million inhabitants; Gross Expenditure on R\&D (GERD) expenditure as \% of GDP; Gross Expenditure on R\&D (PPP\$) per researcher.

\section{Pillar V: R\&D Performance}

Measuring the performance of R\&D activities is not simple. However, the number of scientific articles published is one of the most widely used indicators for measuring the performance of R\&D activities. Scientific articles are an important source of codified knowledge generated in R\&D organizations and universities (Bashir, 2015). In the present study, the following indicators have been used for assessing R\&D performance: Number of scientific articles per million population; Number of citations per publication; H-Index of publications.

\subsubsection{Knowledge}

This dimension covers all those variables that are traditionally thought to be the fruits of inventions and STI activities (Bessant and Venables, 2008). This dimension divides into three pillars.

\section{Pillar VI: Embedded knowledge}

Embedded knowledge of science and technology refers to the extent to which researchers are connected to the global scientific community (Wagner et al., 2002). This pillar includes four indicators: Total patent grants (direct and PCT national phase entries) to resident; Co-authorship index* (\% International Collaboration); Scientific and technical (S\&T) journal articles; Total No. of Publications.

\section{Pillar VII: Absorption of knowledge}

Absorption of knowledge means the ability to assimilate, utilize and exploit acquired or developed technology for social and economic gains. It is very important for developing countries to have the ability to use technologies developed by the advanced countries for their economic benefits (University, INSEAD \&WIPO, 2015). Absorption of knowledge is judged by five indicators: High-technology exports as \% of manufactured exports; Charges for the use of intellectual property, receipts (BoP, current US\$);

\footnotetext{
* \% International collaboration data from Scopus is used as a proxy from for co-authorship index, as the data of Co-authorship index are not available.
} 
Outward FDI stock per capita; Computer and communications service exports; ICT goods exports (\% of total goods exports).

\section{Pillar VIII: Creation of knowledge}

The third pillar of knowledge refers to the creation of knowledge. It includes five indicators that are the result of inventive and innovative activities. This pillar comprises of six indicators: Total patent applications (direct and PCT national phase entries) per million population; Total patent Application (direct and PCT national phase entries) of residents per million population; Total design applications (direct and via the Hague system)per million inhabitants; Total design registrations (direct and via the Hague system); Total utility model applications (direct and PCT national phase entries); Total utility model grants (direct and PCT national phase entries).

\subsubsection{Innovation}

Anything which brings change in your life, this phenomenon is called innovation. It is not easy to present an exact definition of innovation. However, innovation is a process whereby an extended set of activities translate new knowledge into something of value. It can also be a long and painstaking process of translating the initial idea into something useful - and used (e.g. in form of products, processes or services). Whether at the firm or national level, innovation involves a complex system of interacting actors, meaning their interactions can take place across a particular sector, in a region or around a major transnational firm (Bessant and Venables, 2008).This study attempts to capture innovation through different indicators and divides into two pillars.

\section{Pillar IX: Diffusion of old innovations}

This pillar includes the average electricity output in kWh per capita; a composite indicator of logistics performance; and gross capital formation which consists of outlays in additions to the fixed assets and net inventories of the economy including land improvements (fences, ditches, drains), plant, machinery and equipment purchases, the construction of roads, railways and including schools, offices, hospitals, private residential dwellings and commercial \& industrial buildings. The indicators are: Electric power consumption (kWh / capita); Fixed telephone + Mobile cellular subscriptions (per 100 people); Gross fixed capital formation (\% of GDP).

\section{Pillar X: Diffusion of recent innovations}

All countries must adopt innovations to take benefit from the opportunities of the network age. This is measured by diffusion of the internet, indispensable to participate and by imports of goods and services as $\%$ of GDP. Higher technology goods provide viable opportunities to the developing countries as well. Many high-technology sectors are the most dynamic in the global economy. Upgrading the technology content of the manufacturing sector diversifies the economy and creates opportunities in new markets. The internet is far more than a tool for rich countries. By dramatically increasing the access to information while decreasing the cost, the internet has vast potential to aid political participation, to increase people's incomes, and to improve healthcare (Desai et al., 2002). Recent innovations in the form of information communication technologies (ICTs) have become a prerequisite for participation in global economic activities. ICTs are also providing solutions in other fields such as health, the environment, and agriculture (Bashir, 2015). Following are the indicators which are used for recent innovations: Internet users (/1000 people); Imports of goods and services (\% of GDP)); Number of households with a computer per 100 inhabitants; Fixed broadband internet subscribers per 100 inhabitants; Energy imports, net (\% of energy use); Charges for the use of intellectual property, payments (BoP, current US\$); FDI Inward stock; Communications, computer, etc. (\% of service imports, BoP); ICT goods imports (\% total goods imports).

\subsection{Methodology for Developing STI Index}

During literature review, it has been observed that different indices use different methodology to calculate the index. Most of the indices have been calculated by using the same formula that is similar to the formula which is used to calculate the Technology Achievement Index (TAI). 


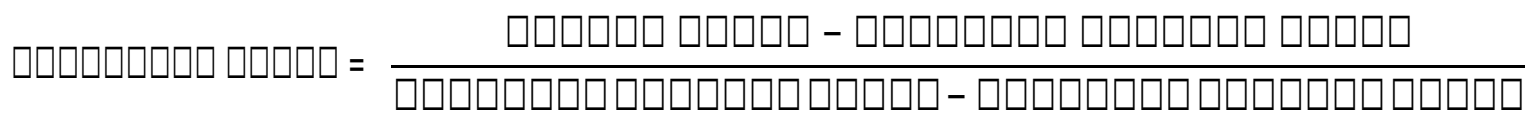

The former mentioned formula is adopted by Desai et al. (2002), (Nasir et al. (2011), Ali et al. (2014), and Ali et al. (2015), and Ali (2017) to calculate the TAI. It has been observed that sometimes this formula provides misleading information about the STI situation of the country. Bashir (2015) also criticized this formula and argued that it overstates the difference between countries. Further, he explained that "A country with the minimum value, even if it is very close to the maximum value, will have a 'zero' score in the index. For example, if country A has 100 Internet users per 100 inhabitants (maximum observed value) and country B has 90 Internet users per 100 inhabitants (minimum observed value), use of this formula will show that country A's score is one (1) and country B's score is zero (0) in the index. In other words, country A's performance is 100 percent and country B's performance compared to country A is zero, which is misleading" The current study develops another formula to calculate the STII to overcome the shortcomings that were mentioned. The current study presents a very simple formula for calculation of STII:

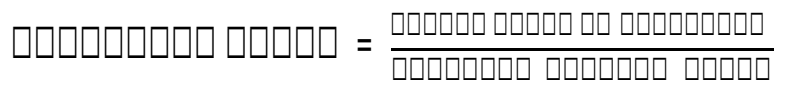

The study has normalized the values of 44 indicators between ' 0 ' and ' 1 ' with ' 0 ' being the lowest and ' 1 ' being the highest.

First, the maximum values of the forty four (44) constituent's indicators are extracted from the compiled data in each country of interest for every year and a table of the goal posts for calculations is constructed (Table 2).

Second, the values of the different indicators are standardized to a scale from 0 to 1 using goalposts, such that an indicator value that is equal to the upper goalpost will be normalized to 1 and a value equal to the lower goalpost will be normalized to 0 , according to the formula given in equation (3.1).

Third, the index of each pillar is calculated by the same procedure used for the overall index; that is the simple mean of sub-indicators. In the STII, each pillar contains its own indicators. The index for each pillar is calculated as the simple average of the indicator indices in that pillar.

Fourth, dimension index is calculated by taking a simple average of its pillars indices.

Fifth, the STII in turn, is the simple average of these four dimensions indices.

\subsubsection{Weighting and Aggregation}

An important issue is that of weighting of different indicators and dimensions. It is beyond the scope of this study to judge which indicator has a greater role in STI progress. The overall STII is built with the weighting of all four dimensions equally. The pillars in each dimension are given equal weight, and the dimensions are given equal (one-quarter) weight in the final index. However, double weightage is given to some individual indicators in each pillar like Patents, Publications, R\&D expenditure etc. The index of each pillar is based on simple average of its indicators indices. Dimension index is calculated by the simple average of its pillars indices. STII value is calculated by the simple average of these four dimensions indices.

\subsubsection{Data Collection and Sources}

It is difficult, expensive and time-consuming to collect the data and information for the forty four indicators directly from data sources in every country in the world. For reasons of practicality, therefore, we rely on the statistical publications and databases of major international organizations. The data have been 
taken primarily from reliable and highly trusted sources such as the Human Development Reports of the United Nations Development Programme (UNDP), database of the SCOPUS; Scimago Journal \& Country Rank (SJR), database of World Intellectual Property Organization (WIPO), databases of the UNESCO Institutes of Statistics (UIS) and publications of the World Bank (WB). Data from 1995 to 2015 of gross capital formation and STI of countries have been retrieved from authenticated sources like World Bank, UNESCO, SCOPUS, and WIPO. The indicators and their data sources have been illustrated in Table 1.

\subsubsection{Estimation of Missing Value for an Indicator}

$85 \%$ of the countries under study have data for more than 30 indicators out of 44 ; while $15 \%$ countries have data for less than 30 indicators. Details of available indicators for every country and strength are presented in Appendix - II.

Two techniques (linear interpolation and forecasting) have been used to estimate missing values of individual indicators. Linear interpolation has been applied to estimate the missing data between two sets of data points. Missing data for year/s of an indicator between two years of available data were calculated in an Excel spreadsheet using the formula given below:

$$
\text { Missing Data }=\text { Previous year data }+\frac{(\text { Last year data }- \text { First year data })}{1+\text { Number of year/s }(\text { you want to estimate })}
$$

Forecasting technique has been preferred for estimating future data values based on present and past data values.Calculating the Science, Technology, and Innovation Index (STII): an example

Table 2. Goal Posts for Calculating Pillar III: Human Skills Development of the STII

\begin{tabular}{|l|l|l|}
\hline Indicator Name & $\begin{array}{l}\text { Observed } \\
\text { maximum } \\
\text { value }\end{array}$ & $\begin{array}{l}\text { Actual Value of } \\
\text { indicator of Z } \\
\text { Country }\end{array}$ \\
\hline $\begin{array}{l}\text { Gross enrolment ratio in science, both sexes at } \\
\text { tertiary level }\end{array}$ & 24.047 & 13.00 \\
\hline $\begin{array}{l}\text { Gross enrolment ratio, primary to tertiary, both sexes } \\
(\%)\end{array}$ & 96.151 & 56.00 \\
\hline Pupil-teacher ratio at tertiary level & 76 & 66.00 \\
\hline
\end{tabular}

- Indicator Index

Indicator index is calculated by the formula presented in Eq.3.1:

Gross tertiary science enrolment index $=(13 / 24.047)=0.540$

Gross enrolment ratio index $=(56.00 / 96.151)=0.582$

Pupil-teacher ratio at tertiary level $=(66.00 / 76.00)=0.868$

- Pillar Index

Pillar index (Human Skills Index is presented as an example) is calculated as:

Human skills index $=(0.540+0.582+0.868) / 3=0.663$

Similarly, the index of each pillar has been calculated.

- Dimension Index:

The dimension index is calculated by taking a simple average of its pillars indices. For example:

a. Support for STI Activities Index : $=(0.24+0.54+0.66) / 3=0.48$

b. Research and Development $(\mathrm{R} \& \mathrm{D})$ Index $=(0.15+0.11) / 2=0.13$ 
c. Knowledge Index $=(0.40+0.21+0.13) / 3=0.246$

d. Innovation Index $=(0.23+0.45) / 2=0.34$

- $\quad$ Science, Technology and Innovation Index (STII)

The STII in turn, is the simple average of these four dimensions indices.

STII $=(0.48+0.13+0.246+0.34) / 4=0.299$

\subsection{Ranking of Nations on the Basis of STII Value}

An STII is developed for 21 years from 1995 to 2015 for the top 100 economies for which data were available and of adequate quality, as shown in Table 3. Despite efforts to collect the data for forty-four

(44) indicators, data for patents and IP charges were not available for a number of nations in the developing world. A lack of data of any country might be assumed to represent that little formal innovation is taking place. Therefore, a value of zero for the missing indicator has been used for calculation purposes in such cases. Table 3 presents the STII for 1995 and 2015 of 100 countries and rank of countries by the year 2015. The ranking and STII value for other years are not presented here due to space limitations, but ranking and STII values for each year from 1995-2015 is presented in Appendix I. The estimates of STII are interesting and disappointing as well, as they illustrate the growth and limitations of the science, technology and innovation progress of nations. The STII values show great disparities not only among the countries as a whole but also within the group of countries like developed and developing countries. The highest STII value is 0.582 for the USA, while the lowest value is 0.090 for the Congo Dem Republic. Ali (2017), Ali, et al. (2015), Nasir, et al. (2011) and Desai, et al. (2002) classified the countries into four groups on the basis of TAI values. However, contrary to these studies, the countries have been classified into six groups, based on their STI values as:

- $\quad$ Leaders (STII $\geq 0.350)$

- Potential Leaders $(0.300 \leq \mathrm{STII} \leq 0.349)$

- Dynamic Adapters $(0.250 \leq \mathrm{STII} \leq 0.299)$

- Slow Adopters $(0.200 \leq \mathrm{STII} \leq 0.249)$

- Marginalized Countries $(0.150 \leq \mathrm{STII} \leq 0.199)$

- Laggard (STII <0.150)

\subsubsection{The Leaders (TAI $>0.350$ )}

Although Ali (2017), Ali, et al. (2015), Nasir, et al. (2011) and Desai, et al. (2002) used a TAI value greater than 0.5 for leaders, we adopt a STII value of 0.350 for leaders in the current study to capture the top 16 countries of the world. This group comprises sixteen countries which are highly developed and at the cutting edge of innovation, topped by the USA, China, Iceland, Singapore and Switzerland in the 2015 rankings (Table 3).

Table 3. Science Technology Innovation Index (STII) (1995 and 2015)

\begin{tabular}{l|l|l|l|l}
\hline \multirow{2}{*}{ Country } & \multicolumn{2}{l|}{2015} & \multicolumn{2}{l}{1995} \\
\cline { 2 - 5 } & Rank & STII & Rank & STII \\
\hline Leaders (STII $\geq 0.350)$ & \multicolumn{4}{l}{} \\
\hline United States & 1 & 0.582 & 1 & 0.605 \\
\hline China & 2 & 0.455 & 37 & 0.223 \\
\hline Iceland & 3 & 0.416 & 8 & 0.371 \\
\hline Singapore & 4 & 0.396 & 22 & 0.300 \\
\hline Switzerland & 5 & 0.393 & 12 & 0.352 \\
\hline Sweden & 6 & 0.392 & 6 & 0.382 \\
\hline Germany & 7 & 0.383 & 5 & 0.387 \\
\hline Denmark & 8 & 0.377 & 10 & 0.357 \\
\hline
\end{tabular}

\begin{tabular}{l|l|l|l|l}
\hline \multirow{2}{*}{ Country } & \multicolumn{2}{|l|}{2015} & \multicolumn{2}{l}{1995} \\
\cline { 2 - 5 } & Rank & STII & Rank & STII \\
\hline Saudi Arabia & 51 & 0.224 & 70 & 0.169 \\
\hline Cyprus & 52 & 0.223 & 40 & 0.208 \\
\hline Turkey & 53 & 0.220 & 65 & 0.172 \\
\hline Panama & 54 & 0.218 & 50 & 0.192 \\
\hline UAE & 55 & 0.215 & 35 & 0.226 \\
\hline Bahrain & 56 & 0.214 & 42 & 0.205 \\
\hline South Africa & 57 & 0.214 & 51 & 0.192 \\
\hline Costa Rica & 58 & 0.212 & 80 & 0.154 \\
\hline Ukraine & 59 & 0.209 & 45 & 0.201 \\
\hline
\end{tabular}




\begin{tabular}{|c|c|c|c|c|c|c|c|c|c|}
\hline Korea, Rep. & 9 & 0.376 & 21 & 0.304 & Uruguay & 60 & 0.205 & 46 & 0.200 \\
\hline Australia & 10 & 0.368 & 7 & 0.372 & Vietnam & 61 & 0.203 & 76 & 0.160 \\
\hline Japan & 11 & 0.366 & 4 & 0.399 & Philippines & 62 & 0.202 & 41 & 0.206 \\
\hline Netherlands & 12 & 0.363 & 15 & 0.326 & Venezuela & 63 & 0.201 & 79 & 0.157 \\
\hline Finland & 13 & 0.361 & 3 & 0.406 & \multirow{2}{*}{\multicolumn{5}{|c|}{$\begin{array}{l}\text { Marginalized Countries }(0.150 \leq \mathrm{STII} \leq \\
0.199)\end{array}$}} \\
\hline Canada & 14 & 0.359 & 2 & 0.411 & & & & & \\
\hline Israel & 15 & 0.359 & 9 & 0.369 & Ecuador & 64 & 0.198 & 59 & 0.176 \\
\hline Austria & 16 & 0.351 & 16 & 0.322 & Thailand & 65 & 0.197 & 61 & 0.174 \\
\hline \multicolumn{5}{|c|}{ Potential Leaders $(0.300 \leq \mathrm{STII} \leq 0.349)$} & Romania & 66 & 0.197 & 53 & 0.190 \\
\hline Belgium & 17 & 0.344 & 23 & 0.298 & Iran & 67 & 0.196 & 56 & 0.184 \\
\hline France & 18 & 0.336 & 11 & 0.353 & Peru & 68 & 0.196 & 74 & 0.165 \\
\hline Norway & 19 & 0.333 & 14 & 0.339 & Tunisia & 69 & 0.195 & 62 & 0.174 \\
\hline Slovenia & 20 & 0.330 & 24 & 0.279 & Pakistan & 70 & 0.193 & 28 & 0.262 \\
\hline \multirow{2}{*}{$\begin{array}{l}\text { United } \\
\text { Kingdom }\end{array}$} & \multirow[b]{2}{*}{21} & \multirow[b]{2}{*}{0.330} & \multirow{2}{*}{13} & \multirow{2}{*}{0.339} & Guatemala & 71 & 0.193 & 78 & 0.158 \\
\hline & & & & & Puerto Rico & 72 & 0.193 & 77 & 0.158 \\
\hline Luxembourg & 22 & 0.328 & 17 & 0.316 & Indonesia & 73 & 0.190 & 84 & 0.147 \\
\hline Qatar & 23 & 0.321 & 29 & 0.255 & Algeria & 74 & 0.190 & 85 & 0.147 \\
\hline Ireland & 24 & 0.311 & 30 & 0.249 & Azerbaijan & 75 & 0.189 & 93 & 0.124 \\
\hline Italy & 25 & 0.308 & 18 & 0.312 & Libya & 76 & 0.188 & 83 & 0.148 \\
\hline Spain & 26 & 0.306 & 25 & 0.275 & Kazakhstan & 77 & 0.187 & 73 & 0.166 \\
\hline Czech Rep. & 27 & 0.300 & 36 & 0.224 & Syria & 78 & 0.183 & 26 & 0.268 \\
\hline \multicolumn{5}{|c|}{ Dynamic Adapters $(0.250 \leq \mathrm{STII} \leq 0.299)$} & Kenya & 79 & 0.182 & 95 & 0.114 \\
\hline Greece & 28 & 0.299 & 27 & 0.263 & Oman & 80 & 0.182 & 89 & 0.137 \\
\hline Russian & 29 & 0.296 & 19 & 0.309 & Tanzania & 81 & 0.181 & 44 & 0.202 \\
\hline Jordan & 30 & 0.273 & 20 & 0.305 & Trinidad & 82 & 0.177 & 88 & 0.137 \\
\hline Hungary & 31 & 0.272 & 33 & 0.234 & Lebanon & 83 & 0.174 & 90 & 0.136 \\
\hline New Zealand & 32 & 0.267 & 31 & 0.248 & Sri Lanka & 84 & 0.173 & 82 & 0.151 \\
\hline Hong Kong & 33 & 0.260 & 39 & 0.218 & Egypt & 85 & 0.170 & 75 & 0.163 \\
\hline Brazil & 34 & 0.256 & 43 & 0.204 & Mexico & 86 & 0.170 & 81 & 0.152 \\
\hline Portugal & 35 & 0.254 & 55 & 0.185 & Nigeria & 87 & 0.170 & 67 & 0.170 \\
\hline \multicolumn{5}{|c|}{ Slow Adopters $(0.200 \leq \mathrm{STII} \leq 0.249)$} & Morocco & 88 & 0.169 & 86 & 0.143 \\
\hline Croatia & 36 & 0.249 & 52 & 0.191 & El Salvador & 89 & 0.166 & 92 & 0.125 \\
\hline Macao & 37 & 0.248 & 63 & 0.173 & Yemen, Rep. & 90 & 0.166 & 72 & 0.167 \\
\hline India & 38 & 0.245 & 38 & 0.220 & Dominican & 91 & 0166 & & \\
\hline Malaysia & 39 & 0.244 & 32 & 0.236 & Rep. & & & 87 & 0.142 \\
\hline Kuwait & 40 & 0.244 & 34 & 0.230 & Cuba & 92 & 0.159 & 91 & 0.132 \\
\hline Poland & 41 & 0.244 & 54 & 0.188 & Cameroon & 93 & 0.154 & 97 & 0.109 \\
\hline Lithuania & 42 & 0.240 & 47 & 0.197 & Ethiopia & 94 & 0.154 & 99 & 0.091 \\
\hline Latvia & 43 & 0.233 & 66 & 0.172 & \multicolumn{5}{|c|}{ Laggard (STII < 0.150) } \\
\hline Serbia & 44 & 0.233 & 71 & 0.167 & Sudan & 95 & 0.146 & 64 & 0.173 \\
\hline Chile & 45 & 0.231 & 49 & 0.194 & Uzbekistan & 96 & 0.144 & 69 & 0.169 \\
\hline Slovak Rep. & 46 & 0.230 & 68 & 0.170 & Bangladesh & 97 & 0.133 & 96 & 0.111 \\
\hline Belarus & 47 & 0.229 & 57 & 0.182 & Iraq & 98 & 0.131 & 98 & 0.097 \\
\hline Colombia & 48 & 0.229 & 58 & 0.179 & Cote d'Ivoire & 99 & 0.125 & 94 & 0.119 \\
\hline Bulgaria & 49 & 0.229 & 48 & 0.196 & \multirow{2}{*}{$\begin{array}{l}\text { Congo Dem } \\
\text { Rep. }\end{array}$} & \multirow{2}{*}{100} & \multirow{2}{*}{0.120} & \multirow[b]{2}{*}{100} & \multirow[b]{2}{*}{0.090} \\
\hline Argentina & 50 & 0.225 & 60 & 0.174 & & & & & \\
\hline
\end{tabular}

These countries have reached an excellent level of development of human skills and effectively diffused old technologies within their societies. They are leveraging recent technologies very well and can be described as being at the cutting edge of technological innovation and consequently as leaders in science 
and technology, trade, industry and business (Ali, et al., 2015).

In this group, the USA, Sweden and Austria seem to be successful in retaining their position from 1995 to 2015, while China, Singapore, Korea, Switzerland, Iceland, Germany, and Denmark improved 35, 18, 12, 7, 5, 2 and 2 points respectively in their ranking thus able to secure their place in the leader's category. Declines in the scores of Canada, Finland, Japan, Israel, Netherlands, and Australia can be seen. The performance of China is particularly remarkable in terms of growth in science technology and innovation achievement with the greatest increase from 1995 to 2015 (Table 3).

\subsubsection{Potential Leaders $(0.300 \leq \mathrm{TAI} \leq \mathbf{0 . 3 4 9})$}

11 countries fall into this category. This group consists of both developed and fast developing countries which have invested in human skill development and used older technologies extensively but are behind the leaders in innovation. Countries of this group are weak in one or two dimensions like technology creation and recent innovation. Most of the countries in this group have similar skill levels as the leader countries. Some countries show very good performance in STI achievement; for example, Czech Republic, enhanced 9, while Belgium, Qatar, Iceland improved 6 points during 21 years. Other countries like France, United Kingdom, Norway, Luxemburg, and Italy ranked at 11, 13, 14, 17 and 18 respectively in 1995 could not retain their position and have fallen into the category of potential leaders in 2015 (Table 3).

\subsubsection{Dynamic Adapters (0.250 $\leq$ STII $\leq$ 0.299)}

Eight countries are placed in this category. Four countries Portugal, Brazil, Hong Kong and Hungry improved 20,11, 6 and 2 points in their ranking during 21years and are placed at 35, 34, 33, and 31 positions in 2015 while declining trends can be seen in other four countries. All these countries in the group have the capacity to enhance their STI capabilities.

\subsubsection{Slow Dynamic Adapters (0.200 $\leq$ STII $\leq \mathbf{0 . 2 4 9 )}$}

There are 28 countries in this group, with Croatia at the top while Venezuela at the bottom. A large number of developing countries are presented in this group. They are speedily expanding their use of new technologies such as internet and telecommunication (i.e., cellular mobile phone networks) which are imperative for high tech industries, but they are still behind in adopting and diffusing old technologies such as electricity, telephone, roads, railways, air and sea transportation which are the basic foundations of technological development. Countries belonging to this group plan to utilize new technologies through a number of techniques. Among them, Malaysia, Turkey, and India have developed significant hightechnology industries and technology hubs. Apart from India, their human skill development level is considerable and continuing to improve further. India, Philippines, Vietnam, and Turkey are the 2nd, 12th, 14th and 19th most populous countries in the world, are also placed in this category and ranked at 38, 62, 61and 53 in 2015 (Table 3). These large and heavily populated countries need to spend heavily on human capital as well as investing in the diffusion of old technologies.

\subsubsection{Marginalized Countries $(0.150 \leq \mathrm{STII} \leq \mathbf{0 . 1 9 9})$}

This group consists of 31 countries with Ecuador at the top and Ethiopia at the bottom (Table 3). The countries in this group are not only weak in technology creation and diffusion of recent innovations, but also in human skill development and the use and spread of old technologies. Large parts of the population in these countries are deprived of basic necessities like electricity, health, clean water and telecommunication. Pakistan and Nigeria with the 6th and 8th largest population in the world are especially low in the dimension of human skill development, which is a major impediment to their economic growth and contribution to the global knowledge-based economy. This group of countries would need to invest heavily in the education sector in order to improve their human skills level. Better attention for the diffusion of old technologies is also advisable for marginalized countries. 


\subsubsection{Laggard (STII $<0.150)$}

These countries lag behind in almost every pillar of STI achievement. Support of STI activities, knowledge, particularly in innovation have a long way to go in these countries. Consequently, the situation regarding technology creation and diffusion of recent technologies is still poor. Bangladesh with the 8th largest population in the world is behind all 100 countries in the dimension of human skill development, which is a major obstacle in Bangladesh's knowledge based sustainable economic growth and its significant participation in the global knowledge based economy.

\section{Science Technology Innovation (STI) Scenario in Selected East and South Asian Countries (ESACs)}

This study selects Eight East and South Asian countries (ESACs) include four from East Asia (China, Japan, Korea, and Malaysia1) and four from South Asia (Bangladesh, India, Pakistan, and Sri Lanka). The reason for selection of these countries is that these countries emerged on the map of world in the same era and have almost similar geographical conditions. However, there is a substantial gap in the economic development of East and South Asian countries. Many East Asian countries were behind at the beginning of their journey compared with south Asian countries. But the situation has reversed now, whereby South Asian countries are far behind than East Asian countries. Some of the world's most populous countries, like China (1st), India (2nd), Pakistan (5th), Bangladesh (8th) and Japan (11th) are placed in selected eight countries. $44.38 \%$ people of the total world population are living in these selected eight countries, making the East and South region the most populous region of the world. More than a quarter of the world's gross domestic product, or GDP (26.57\% in 2015), is apportioned to these eight countries.

The STI situation of the selected East and South Asian countries are illustrated through some important S\&T indicators. STII based on 44 indicators, collectively reflects the actual STI situation of these countries. To explain all indicators of STII is beyond the scope of this study. Therefore, this study discusses some selected indicators of STI, as a representative to state the STI situation of East and South Asian countries.

\subsection{Brief Overview of ESACs in terms of STII}

If we analyse ESACs in terms of the STII, it has been observed that the state of EACs is very impressive while the position of the SACs is generally not satisfactory. China shows a very strong performance in improving its ranking and STII value. China is increasing its budget for education, health and R\&D continuously and performing very well in all four dimensions of STII. In 1995, China was at in 37th position. During 21 years, China has secured its position in the top ten STI advanced countries and is placed at 2nd position in 2015.

The second best ESACs performer is Korea, who was ranked 21st in 1995. After 2010 it rose to the 9th position along with Japan, Austria, Finland, Singapore, United States and Germany. Japan has not successfully retained its 2 nd place position throughout the 21 years from 1995 to 2015, placed at 11th position in 2015. Malaysia's STI performance has also seen it decline to 39th position in 2015 from the 32nd position in 1995. China, Korea and Japan are placed in the "leader" category according to the 2015 rankings while Malaysia in the slow adopter category (Table 3).

In comparison, the situation of SAC in terms of STII is very disappointing. India is included in the category of slow adopters, holding the 38th positions in 2015. Pakistan and Sri Lanka are in the category of marginalized countries in 1995 and 2015 rankings. Pakistan drops 42 points from 28th to 70th, while Bangladesh drops one point from 96th to 97th (Table 3).

1 Malaysia is a vibrant economy and considered as an Asian tiger, it is ahead of other South Asia countries in terms of economic, social, and S\&T indicators. However, the country is closer and similar to East Asian Countries in regard of S\&T development. Accordingly, this study places Malaysia in the group of East Asian countries for comparative purpose, although, Malaysia is the part of South-East Asian region 


\subsubsection{Sub Dimensional Indices of STII.}

Sub dimensional indices of STII are presented in Table 4. China, Japan, and Korea are leading in the first dimensional index (Support for STI Activities), while other ESACs are far behind. The primary reason is that Researcher per million inhabitants (FTE) in Sri Lanka (122.37) Pakistan (175.25), and India (179.00) are very low compared to Korea (7250.00), Japan (5187) Malaysia (2465) and China (1211.00) (Table 4).

Table 4. Sub-Dimensions Indices of STII

\begin{tabular}{|l|l|l|l|l|l|l|l|l|l|l|l|l|l|l|l|l|}
\hline & \multicolumn{4}{|l|}{$\begin{array}{l}\text { Support for STI } \\
\text { Activities Index }\end{array}$} & \multicolumn{4}{l|}{ R\&D Index } & \multicolumn{3}{l|}{ Knowledge Index } & \multicolumn{2}{l|}{ Innovation Index } & \multicolumn{3}{l|}{ STII } \\
\hline Country & 1995 & 2005 & 2015 & 1995 & 2005 & 2015 & 1995 & 2005 & 2015 & 1995 & 2005 & 2015 & 1995 & 2005 & 2015 \\
\hline China & 0.375 & 0.494 & 0.599 & 0.128 & 0.201 & 0.263 & 0.158 & 0.348 & 0.589 & 0.231 & 0.358 & 0.371 & 0.223 & 0.350 & 0.455 \\
\hline Japan & 0.473 & 0.445 & 0.351 & 0.611 & 0.582 & 0.558 & 0.120 & 0.136 & 0.143 & 0.394 & 0.512 & 0.412 & 0.399 & 0.419 & 0.366 \\
\hline $\begin{array}{l}\text { Korea, } \\
\text { Rep. }\end{array}$ & 0.362 & 0.385 & 0.340 & 0.378 & 0.420 & 0.592 & 0.073 & 0.090 & 0.108 & 0.403 & 0.563 & 0.466 & 0.304 & 0.364 & 0.376 \\
\hline Malaysia & 0.310 & 0.351 & 0.307 & 0.105 & 0.124 & 0.221 & 0.117 & 0.101 & 0.094 & 0.414 & 0.414 & 0.355 & 0.236 & 0.248 & 0.244 \\
\hline Bangladesh & 0.174 & 0.196 & 0.198 & 0.066 & 0.090 & 0.069 & 0.097 & 0.118 & 0.105 & 0.108 & 0.148 & 0.162 & 0.111 & 0.138 & 0.133 \\
\hline India & 0.389 & 0.451 & 0.415 & 0.175 & 0.204 & 0.201 & 0.177 & 0.258 & 0.151 & 0.138 & 0.197 & 0.214 & 0.220 & 0.277 & 0.245 \\
\hline Pakistan & 0.289 & 0.260 & 0.231 & 0.068 & 0.105 & 0.117 & 0.098 & 0.108 & 0.100 & 0.593 & 0.584 & 0.326 & 0.262 & 0.264 & 0.193 \\
\hline Sri Lanka & 0.258 & 0.302 & 0.294 & 0.067 & 0.095 & 0.108 & 0.091 & 0.081 & 0.073 & 0.189 & 0.244 & 0.218 & 0.151 & 0.181 & 0.173 \\
\hline
\end{tabular}

Table 5-a. Data for Some Selected Indicators of STII

\begin{tabular}{|l|l|l|l|l|l|l|l|l|}
\hline Country & $\begin{array}{l}\text { Total } \\
\text { patent } \\
\text { grants } \\
\text { to } \\
\text { Resident }\end{array}$ & $\begin{array}{l}\text { Charges for the } \\
\text { use of } \\
\text { intellectual } \\
\text { property, } \\
\text { receipts (BoP, } \\
\text { current US\$) }\end{array}$ & $\begin{array}{l}\text { Internet } \\
\text { users } \\
\text { (per 100 } \\
\text { people) }\end{array}$ & $\begin{array}{l}\text { High- } \\
\text { technology } \\
\text { exports (\% of } \\
\text { manufactured } \\
\text { exports) }\end{array}$ & $\begin{array}{l}\text { Fixed } \\
\text { telephone } \\
\text { Mobile } \\
\text { cellular } \\
\text { subscriptions } \\
\text { (per 100 } \\
\text { people) }\end{array}$ & $\begin{array}{l}\text { Electric } \\
\text { power } \\
\text { consumption } \\
\text { (kWh per } \\
\text { capita) }\end{array}$ & $\begin{array}{l}\text { GER } \\
\text { Primary } \\
\text { po } \\
\text { tertiary, } \\
\text { both } \\
\text { sexes } \\
(\%)\end{array}$ & $\begin{array}{l}\text { Percentage } \\
\text { of students } \\
\text { in tertiary } \\
\text { education } \\
\text { enrolled in } \\
\text { Science }\end{array}$ \\
\hline Bangladesh & $21 \mathrm{a}$ & $902006.17 \mathrm{a}$ & $9.60 \mathrm{a}$ & $0.17 \mathrm{c}$ & $76.61 \mathrm{a}$ & $278.60 \mathrm{c}$ & $31.81 \mathrm{~b}$ & $16.63 \mathrm{~d}$ \\
\hline China & $162680 \mathrm{a}$ & $886670295.00 \mathrm{~b}$ & $49.30 \mathrm{a}$ & $26.97 \mathrm{~b}$ & $110.17 \mathrm{a}$ & $3475.01 \mathrm{c}$ & - & - \\
\hline India & $720 \mathrm{a}$ & $658722433.00 \mathrm{a}$ & $18.00 \mathrm{a}$ & $8.07 \mathrm{~b}$ & $76.61 \mathrm{a}$ & $743.74 \mathrm{c}$ & $55.40 \mathrm{~d}$ & $33.24 \mathrm{~b}$ \\
\hline Japan & $177750 \mathrm{a}$ & $\begin{array}{l}36832562676.00 \\
\mathrm{a}\end{array}$ & $90.58 \mathrm{a}$ & $16.78 \mathrm{~b}$ & $170.3 \mathrm{a}$ & $7752.49 \mathrm{c}$ & $89.93 \mathrm{~b}$ & $17.83 \mathrm{~b}$ \\
\hline Korea Rep. & $97294 \mathrm{a}$ & $5150900000.00 \mathrm{~b}$ & $84.33 \mathrm{a}$ & $27.10 \mathrm{~b}$ & $175.09 \mathrm{a}$ & $10345.60 \mathrm{c}$ & $91.64 \mathrm{a}$ & $35.16 \mathrm{a}$ \\
\hline Malaysia & $344 \mathrm{a}$ & 4328100000.00 & $67.50 \mathrm{a}$ & $43.57 \mathrm{~b}$ & $163.44 \mathrm{a}$ & $4345.47 \mathrm{c}$ & $94.35 \mathrm{~b}$ & $34.08 \mathrm{~b}$ \\
\hline Pakistan & $172 \mathrm{a}$ & $12000000.00 \mathrm{a}$ & $13.80 \mathrm{a}$ & $1.88 \mathrm{~b}$ & $75.98 \mathrm{a}$ & $451.70 \mathrm{c}$ & $70.24 \mathrm{a}$ & - \\
\hline Sri Lanka & $71 \mathrm{~b}$ &. & $25.80 \mathrm{a}$ & $0.99 \mathrm{~b}$ & $115.65 \mathrm{a}$ & $526.81 \mathrm{c}$ & $94.99 \mathrm{~b}$ & $19.90 \mathrm{a}$ \\
\hline
\end{tabular}

Source: World Bank, UIS, WIPO, ' a'= 2014, 'b'=2013, 'c'=2012, 'd'=2011, '-'= data not available: 
Table 5-b. Data for Some Selected Indicators of STII

\begin{tabular}{|c|c|c|c|c|c|c|c|}
\hline & \multirow[t]{2}{*}{ Country } & \multicolumn{2}{|c|}{$\begin{array}{l}\text { Total No. of } \\
\text { Publication } \dagger\end{array}$} & \multicolumn{2}{|c|}{$\begin{array}{l}\text { Government Expenditure } \\
\text { on Education, total ( } \% \text { of } \\
\text { GDP) } €\end{array}$} & \multicolumn{2}{|c|}{$\begin{array}{l}\text { Researchers } \quad \text { Per } \\
\text { million Inhabitants } \\
(\text { FTE }) ¥\end{array}$} \\
\hline & & 1995 & 2015 & 1996* & 2015 & 1995 & 2015 \\
\hline \multirow{4}{*}{ 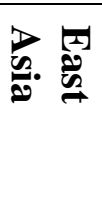 } & China & 24496 & 416409 & 1.848 & - & 468.50 & 1211.00 \\
\hline & Japan & 79157 & 109305 & 3.506 & $3.771^{\mathrm{c}}$ & 4822.50 & 5187.00 \\
\hline & Korea & 7504 & 73433 & 2.974 & $4.618^{\mathrm{a}}$ & 2253.00 & 7250.00 \\
\hline & Malaysia & 828 & 23414 & 4.343 & $4.980_{d}$ & 42.75 & 2465.25 \\
\hline \multirow{4}{*}{ 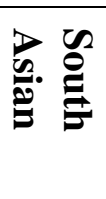 } & Bangladesh & 493 & 3011 & 1.821 & $2.179^{d}$ & .. & .. \\
\hline & India & 19688 & 123206 & 3.066 & $3.841^{\mathrm{b}}$ & 162.50 & 179.00 \\
\hline & Pakistan & 781 & 10962 & 2.817 & $2.661^{\mathrm{d}}$ & 75.50 & 175.25 \\
\hline & Sri Lanka & 177 & 1255 & 2.958 & $2.182^{\mathrm{d}}$ & 201.25 & 122.37 \\
\hline
\end{tabular}

Source: $\uparrow$ SCOPUS Data: $€$ WDI, World Bank: ¥UIS Data, UNESCO: * Data of 1995 is not available; we have to use data for 1996 for comparison. ' $a$ '=2012, 'b'=2013, 'c'=2014, 'd'=2015, '-'= Data is not available,

Korea (35.16) is on the top in enrolment in science at the tertiary level, an important indicator of Support for STI Activities Index. The value of high-technology export (\% of manufactured exports) of Malaysia (43.57) is very high while the other ESACs, including Bangladesh (0.17), Sri Lanka (0.99), Pakistan (1.88), India (8.07), Japan (16.78), China (26.97) and Korea (27.10) have low values (Table 5-a). Korea is on the top in two dimensional indices (Innovation Index and R\&D Index) among ESACs. Electricity is the basic necessity of life as well as it being a key factor for industrial progress. Electric power consumption ( $\mathrm{kWh}$ per capita) of Korea (10345.60) is high relative to other ESACs, including Bangladesh (278), Pakistan (451.71), Sri Lanka (526.18), India (743.74), China (3475.01), Malaysia (4345.47) and Japan (7752.49) (Table 5-a). China is on the top in knowledge index. The primary reason is that the number of patents granted to residents per million in Bangladesh (21), Sri Lanka (71) Pakistan (172), Malaysia (344) and India (720) are very low compared to Korea (97294), China (162680), and Japan (177750) (Table 5-a).

\section{Conclusion and Policy Implications}

On the basis of the STII values, facts and figures presented in this study, it can be concluded that most of the South Asian countries (SACs) are not only far behind scientifically and technologically but also weak in human development. If we take a bird's eye view on the history of these selected eight East and South Asian countries (ESACs), we have found that they started their journey in similar conditions. In contrast, the East Asian countries (EACs) seem to be very developed scientifically, technologically and economically. The STII results show that the three East Asian countries under study have an index value above 0.350 hence they are placed in the leader category, one East Asian country (Malaysia) and one South Asian countries (India) are in the slow adopter category and other two (Pakistan and Sri Lanka) are classified as marginalized countries while Bangladesh in laggard list. South Asian countries have a long voyage of scientific and technological development to catch up. However, East Asian countries are still behind some OECD countries in terms of human development. They also have to work hard to pass the level of economic development found in OECD and European countries. The results of STII also indicate that the majority of South Asian countries have very low capacity of scientific, technological and innovative progress, readiness and preparedness to contribute in the global knowledge-based economy. That is why the gap between South Asian and East Asian countries and other developed countries is expanding with the passage of time.

The study provides valuable and significant information for S\&T policy makers and planners, especially 
for developing countries to formulate STI policies. The results can help them to decide where to take the first step in the long voyage of building adequate scientific and technological capabilities aligned to the socio-economic requirements of their people. The STI results clearly indicate that only EACs are advanced enough to be placed in the leader category, while SACs are placed in the categories of dynamic adopter and marginalized countries. It is proposed that ESACs, especially SACs, require the capability to manage and adapt new creation, technologies for their local needs. To adopt and disseminate modern scientific innovative technologies, ability and knowledge are required but the lack of scientific \& technical knowledge and human skill make conditions in these countries unfavourable. SACs are not only far behind in STI but also in economic and human development. Although SACs are enriched with natural resources, they are unable to fully utilize these resources to the benefit of the public owing to these deficiencies in capacity. SACs under study are still lagging behind in old inventions and utilities, such as telecommunications and electricity, and completely unable to adopt recent high tech innovations. Large portions of rural areas are still deprived of basic technologies and utilities (telephones and electricity) which are structural and functional units of scientific and technological progress that serve as prerequisites to adopt and diffuse the new advanced technologies and innovation in the $21^{\text {st }}$ century.

Technology simply cannot be spread and the capacity to innovate cannot be attained without the vital presence of energy infrastructure (gas and electrical power). It is a mistake to assume that by applying external knowledge and equipment, the technology can be easily transferred, diffused and adopted. Actually, to adopt and implement new technology in a country, a minimum level of infrastructure and capacity is required. Therefore, SACs have to improve their capacity building to be able to consume foreign new innovative technologies and integrate them into their countries. This will enable them to create and develop new technologies to fulfil their local requirements.

Momentous action is needed to accelerate the technological progress in SACs. Improvement in human skills, in particular, is vital to boost technological competency. Although, Japan and Korea perform well in the gross enrolment ratio, they have yet to achieve a $100 \%$ literacy rate. The gross enrolment ratio of students in science at the tertiary level is not very good in ESACs, except in Korea and Japan. The question arises, is the education system of the ESACs satisfactory to encounter the challenges of the twenty-first century? Unfortunately, the answer at this time is 'NO'.

To achieve the needed improvements in their citizens' human skill level, ESACs must increase their educational and R\&D expenditure. The results of STII also indicate that the technological readiness and preparedness to participate in the global knowledge-based economy of SACs countries is very low compared to EACs. That is why the gap between SACs and EACs countries is increasing with passage of time. There is a large gap within EACs and SACs countries for the indicators examined in this study. For instance, in terms of publications, India (123206), Japan (109305), Korea (73433), Malaysia (23414), Pakistan (10962), Bangladesh (3011) and Sri Lanka (1255) are far behind than China (416409) in 2015 (Table 5-b). Malaysia spends 4.98 per cent of GDP on education which is two times higher than Pakistan which spends only 2.66 per cent of GDP on education in 2015 (Table 5-b). Sri Lanka spends 0.23 per cent of GDP on R\&D which is seventeen times less than 4.15 per cent of GDP of Korea in 2013. This failure and worsening condition of SACs is the result of lack of support from political leaders and the failure of existing policies to solidify the importance of the components of the engine for economic growth and development which are education, research \& development, science, technology and innovation policy. The efforts made by SACs in the fields of education and STI are not adequate to meet their needs. Therefore, it is critical for ESACs to realize the importance and significance of education, research \& development and STI impacts on economic growth, human and industrial development. They can follow the model of rising economies like Korea, Singapore, Hong Kong and Taiwan who have been spending a high percentage of their budget on the basic facilities of twenty-first century global life, applied research, health and education. In the long run, ESACs and especially SACs have to invest more in a number of areas. These include the energy sector (to increase capacity for power and gas), education, research \& development (to obtain the spillover effect of investments on invention), technology creation (in the form 
of high-tech export, patents, and royalties) and human development. The direct and indirect implications of the study have been summarized in point form as follows:

\section{Direct Implications}

i. $\quad$ STI policy makers and planners may use the STII (which situate the country preparedness and readiness to participate in global knowledge base economy). Ranking of countries on the basis of STII values may be used in futuristic studies and very useful to develop and formulate the STI Policy of the country.

ii. There are many other indicators which are helpful to improve the STI level and useful to increase the output like: communication technology (ICT) and high-tech imports. There is dire need for developing countries to improve the uptake of ICT and high-tech import by relaxing excise rates, tariffs, duties, and quotas until they become self-sufficient in creation and innovation of new technologies.

iii. Results of study (on the basis of STII value) indicate that developing economies are very weak in creation of technologies. There is no coordination between R\&D organizations, universities and industries to produce high quality end products. Therefore, developing countries need to create university-industry linkage not only within country but across the region as well. So, strong implication of policy should be implemented by the government and a target for the R\&D budget should be set. Moreover, a strategic policy is required to ensure that STI data of each country should be reported yearly at national level at first and then government should set a benchmark value to enhance it each year.

\section{Indirect Implications}

i. Need for a vision of the future assessment (identifying what the priority areas in STI are)

ii. Quality enhancement (design and launch programme standards which ensure quality services according to local needs)

iii. Bridging the links between research \& development and practice (to create up-to-date research environments at universities R\&D organizations)

iv. Taking initial steps to support the synthesis of existing STI knowledge and to build and expand the national STI knowledge base

\section{Limitations of Study}

One of the problems faced in the current study, which is common to all statistical studies, was related to the availability of reliable data. The index (STII) is incomplete in its coverage of countries, limited in to 100 countries out of the 264 countries and territories of the world as per World Bank (World Bank, 2017). We attempted to obtain data for all forty four sub-indicators for each country, relying upon the statistical publications and databases of major international organizations. Data of all forty four indicators for all 100 countries included in the study was not available, therefore missing values have been estimated by linear interpolation and forecasting where required, but we were forced to use zero for STII values where data of the country is not available.

\section{Future Outlook}

Finally, the STII appears to be a reasonable composite S\&T indicator for assessing the technological readiness of a nation without concluding anything about its overall S\&T capability. As such, it may be useful for detailed studies of regional technical capabilities; for example OECD, OIC, and SAARC nations for being of direct interest, oil-producing countries due to their prominent role in the world economy, and Central Asian republics as a future source of the world's energy supplies. 
The indices of the individual dimensions of the STII could provide meaningful information and insight about level of technology progress and economic development of developing countries as well as different regions of world. We would suggest a more detailed analysis of these as a subject of future research.

Ideally, the efforts following from the direct and indirect implications listed above would improve the status of lagging nations and raise them into a more equal stance in the knowledge-based global economy

\section{References}

Ali, T. M. (2017). Technological Achievements and Economic Development: The Significance of Technological Achievement Gap in Selected East and South Asian Countries. STI Policy Review, 8(1),113-156.

Ali, T. M., Bashir, T., \& Kiani, A. K. (2015). Assessment of Technological Capabilities of OIC Countries. Science, Technology and Society, 20(1), 114-131.

Ali, T. M., Kiani, A. K., Asrar, M., \& Bashir, T. (2014). Technology Achievement Index of Muslim Nations - Ranking and Comparative Study. Science, Technology and Development, 33(2), 49-62.

Archibugi, D., \& Coco, A. (2004). A new indicator of technological capabilities for developed and developing countries (ArCO). World Development, 32(4), 629-654.

Archibugi, D., \& Coco, A. (2005). Measuring Technological Capabilities at the Country Level: A Survey and A Menu for Choice. Research Policy, 34, 175 - 194.

Bashir, T. (2015). Global STI Capacity Index: Comparison and Achievement Gap Analysis of National STI Capacities. STI Policy Review, 6(2), 105-145.

Bessant, J and Venables, T. (2008), Creating Wealth from Knowledge, Edward Elgar: Cheltenham.

Chinaprayoon, C. (2007). Science, Technology and Innovation Composite Indicators for Developing Countries. Georgia Institute of Technology.

Commission, E. (2004). European innovation scoreboard 2004: Comparative analysis of innovation performance. Brussels: European Commission.

Desai, M., Fukuda-Parr, S., Johansson, C., \& Sagasti, F. (2002). Measuring the technology achievement of nations and capacity to participate in the network age. Journal of Human Development, 3(1), 95-122.

Ertl, H., Bordt, M., Earl, L., Lacorix, A., Lonmo, c., McNiven, C., et al. (2006). Toward understanding Impact of Science and Technology and Innovation activities. Ottawa, Canada: SIEID, Statistics Canada, Blue Sky II Forum.

Gault, F. (2006). Measuring knowledge and its economic effects: the role Official Statistics. In B. K. Foray, \& B. K. Foray (Ed.), Advance knowledge and the knowledge economy. Cambridge: the MIT press (forthcoming).

Intarakumnerd, P., \& Viotti, E. (2006). ST\&I Indicator for Developing Economies: A Preliminary Mapping of Initiatives and Proposal for the Catch-up Project.

Lall, S., \& Albaladejo, M. (2003). Indicators of the relative importance of IPRs in developing countries. International Center for Trade and Sustainable Development (ICTSD) and United Nations Conference on Trade and Development (UNCTAD).

Nasir, A., Ali, T. M., Shahdin, S., \& Rahman, T. U. (2011). Technology achievement index 2009: ranking and comparative study of nations. Scientometrics, 87(1), 41-62.

Porter, A. L., Roessner, J. D., Newman, N., Jin, X.-Y., \& Johnson, D. M. (2006). High tech indicators: Technology-based competitiveness of 33 nations: 2005 Final report. Technology Policy and Assesment Center. Atlanta: Georgia: Georgia Institute Of Technology.

Porter, M., \& Stern, S. (. (2003). Ranking national innovative capacity: Findings from the national innovative capacity index,. In Global competitiveness report 2003-2004. N. Y.: Oxford University Press.

Schwab, F., \& Sala-i-Martin. (2017). The Global Competitiveness Report (GCR). Newyork: World Economic Forum.

Sener, S., \& Sarıdogan, E. (2011). The Effects of Science-Technology-Innovation on Competitiveness and Economic Growth. Procedia Social and Behavioral Sciences, 24, 815-828. 
Tabatabaeean, S. H., Naghizadehb, R., Khaledia, A., \& Naghizadeh, M. (2010). Technological Capability Monitoring Index, A New Composite Index for Measuring Technological Capabilities of Nations. The 4th National Conference on Management of Technology.

UIS. (2017, March 7). UNESCO. Retrieved March 7, 2017, from UNESCO Institute of Statistics(UIS): http://data.uis.unesco.org/

UNDP. (2001). Human Development Report-2001. United Nations Development Programme(UNDP), New York, Oxford University Press.

UNDP. (2002). Human Development Report. New York, NY 10017: UNDP.

UNDP. (2015). Human Development Report-2015 (Work for Human Development). New York, NY 10017: UNDP.

UNIDO. (2003). Industrial development report 2002/2003: Competing through innovation and learning.

Vienna: United Nations Industrial Development Organization (UNIDO). .

UNIDO. (2004). Industrial development report 2004: Industrialisation, environment and the millennium development goals in Sub-Saharan Africa. Vienna: United Nations Industrial Development Organization (UNIDO).

UNIDO. (2005). Industrial development report 2005: Capability building for catching-up. Vienna: United Nations Industrial Development Organization (UNIDO).

University, C., INSEAD, \& WIPO. (2015). The Global Innovation Index 2015: Effective Innovation Policies for Development. Fontainebleau, Ithaca, and Geneva: Cornell University, INSEAD and WIPO.

Wagner, C. S., Horlings, E., \& Dutta, A. (2002). Can science and technology capacity be measured? Santa Monica, California: Rand Corporation.

WEF. (2002). The Global Competitiveness Report. World Economic Forum (WEF). Oxford University Press, N.Y.

WEF. (2003). The Global Competitiveness Report. New York, New York 10016: World Economic Forum. 